\title{
Host plant-mediated prey preference and consumption by an aphidophagous ladybird, Menochilus sexmaculatus (Fabricius) (Coleoptera: Coccinellidae)
}

\author{
Ahmad Pervez and Satish Chandra
}

\begin{abstract}
The impact of host plant-aphid combination on the prey consumption and prey preference by adult ladybird, Menochilus sexmaculatus (Fabricius) (Coleoptera: Coccinellidae) was studied, using aphid-prey, Aphis craccivora (Koch) and Lipaphis erysimi (Kalt.), in the laboratory. Monotypic aphids, A. craccivora, raised separately on Indian bean, Dolichos lablab L., and poison buttercup, Ranunculus sceleratus L., and L. erysimi cultured on radish, Raphanus sativus L., and mustard, Brassica campestris L., were provided. Adult male and female ladybirds consumed significantly greater number of A. craccivora infested on D. lablab than those on $R$. sceleratus. Similarly, they consumed a greater number of $L$. erysimi raised on $R$. sativus than those on $B$. campestris. The results indicated that host plant allelochemicals/toxicants had a direct effect on the palatability and prey consumption, as the ladybird treated the same aphids differently that was raised on different hosts. Prey preference, using a choice condition, was tested by providing both the aphid species raised on toxic hosts in a common microcosm. Both adult male and female of $M$. sexmaculatus preferably consumed the aphid, A. craccivora-infested $R$. sceleratus over L. erysimiinfested B. campestris in all diet treatments. The preference indices ( $\beta$ and $C$ ) further skewed the results towards $A$. craccivora, which suggest that ladybirds preferred A. craccivora on encountering aphids raised on toxic hosts. It could be concluded that dietary selection in ladybirds depends largely on the aphid-host combination, and a suitable host may aid the augmentative rearing of both aphids and ladybirds.
\end{abstract}

Keywords: Aphids, Aphis craccivora, Brassica, Menochilus sexmaculatus, Diet, Lipaphis erysimi

\section{Background}

Majority of ladybirds (Coleoptera: Coccinellidae) are important predators and biocontrol agents of numerous phytophagous pests, viz. aphids, scale insects, mealy bugs, thrips, mites, and whiteflies (Omkar and Pervez 2004, 2016; Hodek et al. 2012). A thorough understanding of ladybirds' dietary habits can help in maximizing their biocontrol potential (Michaud 2005; Provost et al. 2006; Sloggett 2008a, b; Hodek and Evans 2012; Pervez et al. 2018). However, diet suitability in aphidophagous ladybirds seems unpredictable, as the same aphid can be both toxic and nutritious (Guroo et al. 2017). For instance, earlier reports considered black bean aphid,

\footnotetext{
* Correspondence: ahmadpervez@yahoo.com

Biocontrol Laboratory, Department of Zoology, Radhey Hari Govertment. P.G. College, Kashipur, Udham Singh Nagar, Uttarakhand 244713, India
}

Aphis craccivora (Koch), as unsuitable food for ladybirds (Hodek 1996), due to the presence of toxic allelochemicals, viz. amines canavanine and ethanolamine (Obatake and Suzuki 1985). Ferrer et al. (2008) considered it as a sub-optimal prey, as the larvae feeding on it grew into lighter adults with decreased ovarioles number. On the contrary, recent findings suggested it to be highly nutritious after being raised on Indian bean, Dolichos lablab L. (=Lablab purpureus L.), and recommended it as the most suitable prey for mass rearing of certain aphidophagous ladybirds (Omkar and Mishra 2005; Chaudhary et al. 2016).

Host plant seems to have a direct influence on prey preference and prey suitability in ladybirds (Ferrer et al. 2008; Giorgi et al. 2009). Apart from nutrition, certain host plants provide an ecological refuge to the aphids by 
chemically protecting them from their natural enemies (Chaplin-Kramer et al. 2011). Toxic plant allelochemicals deteriorate the aphid quality and make them unsuitable for predators (Pratt 2008). However, continuous rearing of aphidophagous ladybirds on toxic prey for generations enables the offspring to easily thrive on the toxic prey than the nutritious ones (Rana et al. 2002). Mixing toxic aphids with nutritious ones perhaps compliments the nutrient-deficiency of the former and cumulatively enhances the fitness of ladybirds (Nedved and Salvucci 2008; Guroo et al. 2017). Mustard aphid, Lipaphis erysimi (Kaltenbach), infesting Brassica campestris L. is known to decrease the fitness of certain ladybirds (Omkar and Mishra 2005), as it sequesters toxic allelochemicals from the host plant (Ahuja et al. 2010).

Zig-zag ladybird, Menochilus sexmaculatus [=Cheilomenes sexmaculata] (Fabricius) preferably feeds on $A$. craccivora infesting Indian bean, D. lablab L. (=Lablab purpureus L.) (Omkar and Bind 1998) and thereby optimizes its fitness (Omkar and Bind 2004). It is an oriental ladybird having a wide prey range (Saleem et al. 2014). Its immature stages can easily be reared on mustard aphid, L. erysimi; however, the fecundity and developmental rate were not very boosting (Singh et al., 2008).

Owing to its high abundance of M. sexmaculatus in the agricultural fields of North India, we considered it as a model to determine the ladybird behavior towards aphids cultured on different host plants. The objective of the present investigation was to better understand the status of A. craccivora in terms of prey preference and prey suitability to ladybirds. Also, the difference in the prey consumption, when ladybirds fed on monotypic aphids or mixed aphids, was investigated.

\section{Materials and methods Stock maintenance}

Adults of M. sexmaculatus were collected from the agricultural fields of Kashipur, Uttarakhand, India $\left(30.2937^{\circ} \mathrm{N}\right.$, $\left.79.5603^{\circ} \mathrm{E}\right)$ and brought to the laboratory. These were sexually identified by a careful examination of lower abdominal segments with the help of Trinocular Assembly (Lyzer IS0-9001: magnification $\times 40$ ) connected to a computer. Thereafter, we paired in Petri dishes $(2.0 \times 9.0 \mathrm{~cm}$ diameter) containing sufficient quantity of monotypic aphids, A. craccivora on pieces of leaves/twigs of D. lablab and Ranunculus sceleratus, respectively, and L. erysimi infested on Raphanus sativus and B. campestris, respectively $(n=10)$, and kept in the Environmental Test Chamber (REMI Instruments, India) at controlled conditions (25 \pm $1{ }^{\circ} \mathrm{C}, 65 \pm 5 \%$ R.H and 12L: 12D). The $F_{1}$ eggs laid by the female ladybird from each host plant-aphid combinations were reared on the same host plant-aphid combination till adult emergence. The newly emerged $F_{1}$ adults were sexually identified and isolated in separate Petri dishes $(2.0 \times 9.0 \mathrm{~cm}$ and prey as above $)$ for experiments.

\section{Response to single aphid-host combination}

Twelve-hour starved 10-day-old virgin adult male $M$. sexmaculatus were kept singly in a glass beaker $(11.0 \mathrm{~cm}$ height and $8.5 \mathrm{~cm}$ diameter) containing 100 third instars of aphids (i) A. craccivora infested on twigs of D. lablab, (ii.) A. craccivora on twigs of $R$. sceleratus (iii) L. erysimi on twigs of R. sativus, and (iv) L. erysimi on twigs of $B$. campestris. The beakers were covered by a muslin cloth fastened with rubber bands. The beakers were kept in the environmental test chamber (ETC) (REMI Instruments, India) maintained at above abiotic conditions. After $12 \mathrm{~h}$, the beakers were removed and counted the live aphids to quantify the number of aphids consumed. The experiment was repeated using adult female $M$. sexmaculatus. The experiment was replicated ten times. The data on prey consumption were tested for normality, using Kolmogorov-Smirnoff Test and homogeneity of variance, using Bartlett's Test using statistical software, SAS 9.0 (2002). The data were subjected on number of aphid consumed to one-way ANOVA and compared the means using Tukey's HSD test using SAS 9.0 (2002). Thereafter, the data were subjected on aphids, raised on different host plants and consumed by the two sexes of $M$. sexmaculatus to Factorial ANOVA using "aphid species," "host plant," and "gender" as independent variables and "prey consumed" as dependent variable using SAS 9.0 (2002).

\section{Prey preference}

Prey preference was determined by offering mix-aphids cultured on toxic host plants to the adult male and female $M$. sexmaculatus in a bid to find out the preferred aphid-host combination. For the purpose, the aphids, $A$. craccivora (Ac) cultured on $R$. sceleratus and L. erysimi (Le) cultured on B. campestris, were offered to the adult male and female $M$. sexmaculatus in three ratios, i.e., $A c$ to $L e$ 50:100, 75:75, and 100:50. For the purpose, a single 12-h starved ten-day-old adult male ladybird was kept in a glass beaker $(11.0 \mathrm{~cm}$ height and $8.5 \mathrm{~cm}$ diameter), containing mix proportion of (i) $50 \mathrm{Ac}$ and $100 \mathrm{Le}$, (ii) $75 \mathrm{Ac}$, and $75 \mathrm{Le}$, and (iii) $100 \mathrm{Ac}$ and $50 \mathrm{Le}$ infested on respective toxic host plant twigs. The beaker (as above) was covered and kept in the ETC (conditions as above). After $24 \mathrm{~h}$, the beaker was removed and quantified for the number of aphids consumed (as above). The experiment was repeated, using an adult female of $M$. sexmaculatus as the predator. The entire experiment was replicated ten times.

Manly's preference index (Manly 1972) using formula, $\beta=\log \left(N_{\mathrm{A}} / r_{\mathrm{A}}\right) /\left[\log \left(N_{\mathrm{A}} / r_{\mathrm{A}}\right)+\log \left(N_{\mathrm{B}} / r_{\mathrm{B}}\right)\right]$ for each treatment, where $N_{\mathrm{A}}$ and $N_{\mathrm{B}}$ are number of aphids $\mathrm{A}$ and B 
offered to the adult predator and $r_{\mathrm{A}}$ and $r_{\mathrm{B}}$ are unconsumed aphids. Manly's preference index removes prey depletion error, i.e., it is applicable in those experiments, where killed prey items are not replaced (Cook 1978; Sherratt and Harvey 1993). Adult ladybird prefers aphid $\mathrm{A}$ if $\beta$ is close to 1 , and aphid $\mathrm{B}$ is preferred if $\beta$ is close to 0 . Index value close to 0.5 revealed no preference. $\beta$ for significant difference from a value of 0.5 was tested, using one sample $t$ test in each treatment (SAS 9.0). Prey preference was also determined by $C$ index (i.e., $C=\left(E_{\mathrm{A}} \times N_{\mathrm{B}}\right) /\left(E_{\mathrm{B}} \times N_{\mathrm{A}}\right)$, where $E_{\mathrm{A}}$ and $E_{\mathrm{B}}$ are the number of aphids $\mathrm{A}$ and $\mathrm{B}$ consumed. $\mathrm{C}$ index above 1.0 indicates the preference for aphid $\mathrm{A}$, while below 1.0 indicates the preference for aphid B (Sherratt and Harvey 1993). C index in each treatment was subjected to one sample $t$ test for significant difference from a value of 1.0. The data on number of aphid consumed were subjected to Wilcoxon's matched-pair signed rank test (SAS Version 9.0). The proportions of the two aphids consumed by the adults $M$. sexmaculatus were subjected to two-way ANOVA using "aphid species" and "gender" as independent variables and "proportion of prey consumed" as a dependent variable (SAS 9.0, 2002).

\section{Results and discussion}

Both adult male $(F=25.86 ; P<0.0001 ; \mathrm{df}=3,39)$ and female $(F=45.51 ; P<0.0001 ; \mathrm{df}=3,39)$ of $M$. sexmaculatus consumed significantly greater number of aphids, $A$. craccivora infested on $D$. lablab, followed by $L$. erysimi infested on $R$. sativus (Fig. 1). This revealed that $A$. craccivora cultured on $D$. lablab was the best aphid-host combination culminating in maximum prey consumption. Seemingly, the biochemical contents of D. lablab, like sugars, alcohols, and essential oils (Al-Snafi 2017) made A. craccivora to be highly palatable to $M$. sexmaculatus, resulting in its high consumption. This aphid also infests other hosts, viz. cowpea, glyricidia, and groundnut, which are frequently visited by the ladybirds (Jaba et al. 2010).

The aphids, A. craccivora and L. erysimi, reared on $R$. sceleratus and Brevicoryne brassicae, respectively, were consumed lesser by the two sexes of the ladybirds with insignificant difference between their means (Tukey's range $=3.81$; Fig. 1 ). It seems that $A$. craccivora infesting $R$. sceleratus were less palatable to $M$. sexmaculatus. Ranunculus sp. are known to be rich in toxic secondary metabolites, such as di and tri terpenes, glycosides, steroids, coumarins, phenolic compounds, and flavonoid contents, which may account for the lesser consumption of its herbivore (Hachelaf et al. 2013; Pervez and Kumar 2017). A. craccivora exploits this plant as a host in the months of June to August in North India during the absence of its regular host. Hence, $R$. sceleratus has an ecological significance in terms of providing refuge to A. craccivora along with retaining the ladybirds, particularly $M$. sexmaculatus, during the absence of other host agricultural crops. It is evident from obtained results that palatability and consumption of $A$. craccivora were largely dependent on the host plant rather than its own nutrients. This explains the disparity in the reports by various authors about its suitability to different ladybirds (Omkar and Bind 2004; Omkar and Mishra 2005; Chaudhary et al. 2016).

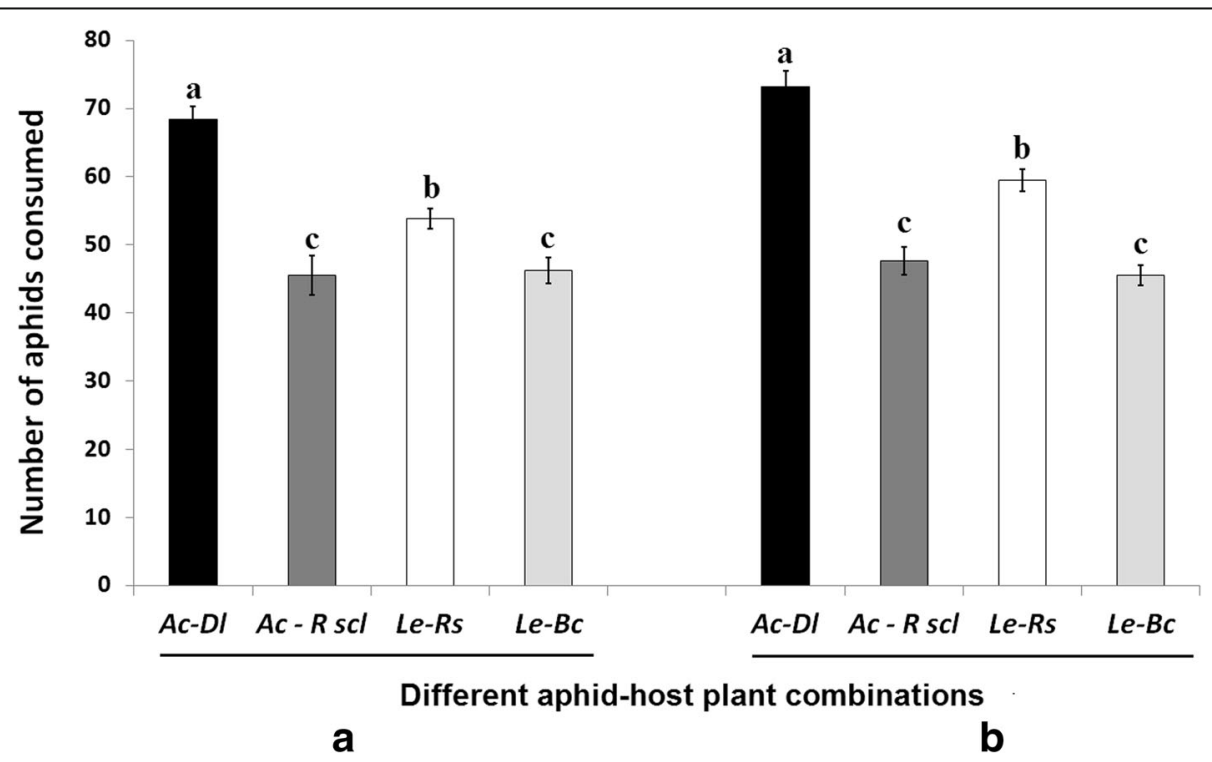

Fig. 1 Number of aphids consumed by adult $\mathbf{a}$ male and $\mathbf{b}$ female of M. sexmaculatus when fed on different aphid-host plant combinations (i.e., (i) $A c-D l=A$. craccivora-D. lablab, (ii) $A c-R s c l=A$. craccivora-R. sceleratus, (iii) $L e-R s=L$. erysimi-R. sativus, and (iv) $L e-B c=L$. erysimi-B. campestris. Error bars denote standard deviation. Bars indicated by the same letter are not statistically different at $P<0.05$ (Tukey's test) 


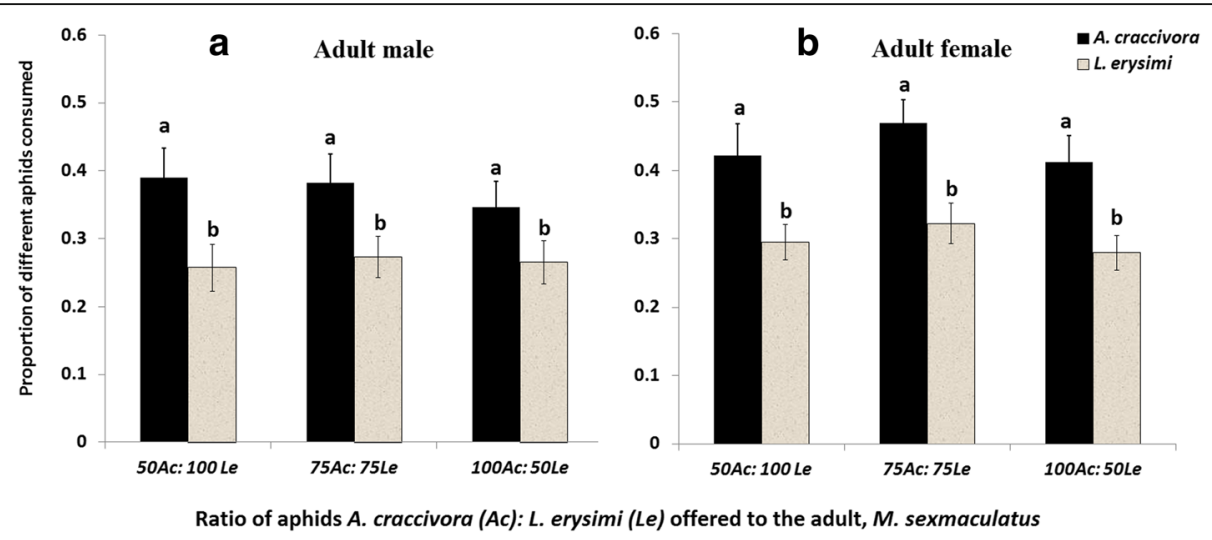

Fig. 2 Proportions of aphid species [A. craccivora (AC) and L. erysimi (Le) reared on R. sceleratus and B. campestris, respectively] consumed by adult $\mathbf{a}$ male and $\mathbf{b}$ female of $M$. sexmaculatus when the aphids were provided in different ratios. Error bars show standard error. Bars indicated by the same letter are not statistically different at $P<0.05$ (Tukey's test)

Adults M. sexmaculatus consumed greater number of $L$. erysimi raised on $R$. sativus than those raised on B. campestris. Brassica plants, particularly B. campestris, have a strong defense system and contain allelochemicals, like glucosinolates, isothiocyanates, nitriles, and phytoalexins (Ahuja et al. 2010). L. erysimi sequesters these allelochemicals, which reduce its palatability to its predators. These chemicals also are lower in their nutritive value and thereby negatively affecting the development and fecundity of its predators (Omkar and Mishra 2005). From ladybirds' perspective, $D$. lablab and $R$. sativus are considered as better hosts for the biocontrol of A. craccivora and L. erysimi, respectively. Two-way ANOVA reveals significantly main effects of "aphid species" $(F=43.29 ; P<0.0001 ; \mathrm{df}=1)$ and "gender" $(F=9.81 ; P=0.003 ; \mathrm{df}=1)$. The interaction "aphid species" $\times$ "gender," however, was not statistically significant $(F=1.54 ; P=0.223 ; \mathrm{df}=1,39)$. The significant main effect of sex on the aphid consumption was due to the difference in the quantitative aphid consumption, as females consumed a greater number of aphids in all aphid-host combinations. This is largely attributed to the size disparity in adults, as females are larger than the males.

The two inferior aphid-host combinations in terms of lesser consumption were used in the prey-preference experiment. Adult male $M$. sexmaculatus significantly preferred aphid $A$. craccivora over $L$. erysimi raised on toxic host plants in all three mixed aphid-diet combinations, i.e., at 50:100 (Ac to $L e)$ ratio $\left(Z_{(1,18)}=-3.7968 ; P=0.0001\right)$, $75: 75$ (Ac to $L e)$ ratio $\left(Z_{(1,18)}=-3.7968 ; P=0.0001\right)$, and 100:50 (Ac to $L e)$ ratio $\left(Z_{(1,18)}=2.3240 ; P=0.0210\right.$; Fig. 2a). Similarly, adult female ladybird preferably consumed $A$. craccivora in the three diet treatments (i.e., at $50 \mathrm{Ac:100} \mathrm{Le}$; $\left.Z_{(1,18)}=-3.753 ; P=0.0002\right), 75$ Ac: 75 Le; $Z_{(1,18)}=-2.4633$; $P=0.0138)$, and $100 A c: 50 \mathrm{Le} ; Z_{(1,18)}=3.1917 ; P=0.0014$, see Fig. 2b). On the contrary, ladybird, Propylea dissecta
(Mulsant), preferred L. erysimi when provided with the same aphid combinations (Pervez and Kumar 2017).

The factorial ANOVA revealed the data on number of aphid consumed to be statistically significant $(F=30.36$; $P<0.0001 ; \mathrm{df}=1)$. There were significant main effects of "host" $(F=154.95 ; P<0.0001 ; \mathrm{df}=1)$, "aphid species" $(F=27.55 ; P<0.0001 ; \mathrm{df}=1)$, and "gender" $(F=4.38$; $P<0.05 ; \mathrm{df}=1)$ on the number of prey consumed (Table 1). This clearly indicates that these independent variables had a major effect on the aphid consumption. The interaction between "aphid species" and "host" was also significant $(F=22.58 ; \quad P<0.0001 ; \quad \mathrm{df}=1)$. However, the interactions between "gender" and "aphid species" ( $F=0.13 ; P=0.7239 ; \mathrm{df}=1)$, "gender" and "host" $(F=2.55 ; P=0.1149 ; \mathrm{df}=1)$, and "aphid species" $\times$ "host" $\times$ "gender" $(F=0.41 ; P=0.5253 ; \mathrm{df}=1)$ were insignificant. Preference indices, viz. $\beta$ and $C$ had significant $t$ values in all the combinations (Table 2), which further corroborates the inference that $M$. sexmaculatus preferred $A$. craccivora over $L$. erysimi despite the former prey being raised on

Table 1 Details of three-way factorial ANOVA using "gender," "host plant," and "aphid species" as independent variables

\begin{tabular}{|c|c|c|c|c|}
\hline Source & df & Mean square & F value & $P$ value \\
\hline Gender & 1 & 174.05 & 4.38 & $P<0.05$ \\
\hline Host plant & 1 & 6160.05 & 154.95 & $P<0.0001$ \\
\hline Aphid species & 1 & 1095.20 & 27.55 & $P<0.0001$ \\
\hline Gender $\times$ host plant & 1 & 101.25 & 2.55 & $P=0.1149$ \\
\hline $\begin{array}{l}\text { Gender } \times \text { aphid } \\
\text { species }\end{array}$ & 1 & 5.000 & 0.13 & $P=0.7239$ \\
\hline $\begin{array}{l}\text { Host plant } \times \text { aphid } \\
\text { species }\end{array}$ & 1 & 897.8 & 22.58 & $P<0.0001$ \\
\hline $\begin{array}{l}\text { Gender } \times \text { host plant } \times \\
\text { aphid species }\end{array}$ & 1 & 16.20 & 0.41 & $P=0.5253$ \\
\hline
\end{tabular}

Tukey's range $=2.81929$ $\mathrm{df}=1$ 
Table 2 Preference indices ( $\beta$ and $C$ ) evaluated from different aphid proportions (Acraccivora: L. erysimi) exposed to M. sexmaculatus in cafeteria experiment

\begin{tabular}{|c|c|c|c|c|c|}
\hline Predator & Aphid ratio & $\beta$ index & $t$ value & C index & $t$ value \\
\hline \multirow[t]{3}{*}{$\begin{array}{l}\text { Adult male } \\
\text { M. sexmaculatus }\end{array}$} & $50: 100$ & $0.700 \pm 0.06$ & $\begin{array}{l}t=5.54 \\
P<0.01\end{array}$ & $1.851 \pm 0.39$ & $\begin{array}{l}t=7.16 ; \\
P<0.01\end{array}$ \\
\hline & $75: 75$ & $0.783 \pm 0.05$ & $\begin{array}{l}t=5.58 \\
P<0.01\end{array}$ & $1.515 \pm 0.25$ & $\begin{array}{l}t=6.03 \\
P<0.01\end{array}$ \\
\hline & 100:50 & $0.716 \pm 0.06$ & $\begin{array}{l}t=6.25 \\
P<0.01\end{array}$ & $1.967 \pm 0.78$ & $\begin{array}{l}t=8.25 \\
P<0.01\end{array}$ \\
\hline \multirow[t]{3}{*}{$\begin{array}{l}\text { Adult female } \\
\text { M. sexmaculatus }\end{array}$} & $50: 100$ & $0.670 \pm 0.06$ & $\begin{array}{l}t=2.14 \\
P<0.05\end{array}$ & $1.539 \pm 0.33$ & $\begin{array}{l}t=2.62 ; \\
P<0.05\end{array}$ \\
\hline & $75: 75$ & $0.615 \pm 0.04$ & $\begin{array}{l}t=2.84 \\
P<0.05\end{array}$ & $1.596 \pm 0.20$ & $\begin{array}{l}t=2.89 \\
P<0.05\end{array}$ \\
\hline & $100: 50$ & $0.565 \pm 0.03$ & $\begin{array}{l}t=2.41 \\
P<0.05\end{array}$ & $1.498 \pm 0.22$ & $\begin{array}{l}t=2.54 ; \\
P<0.05\end{array}$ \\
\hline
\end{tabular}

Ladybird prefers A. craccivora if $\beta$ is close to 1 and L. erysimi if $\beta$ is close to 0 . Similarly, A. craccivora is preferred if the $C$ index is more than 1 and L. erysimi is preferred if the $C$ index is less than 1

toxic host. However, in a similar experiment, larvae and adults of ladybird, Coccinella septempunctata L. prefer to consume L. erysimi over the aphid, Brevicoryne brassicae L. with significantly high values of $\beta$ and $C$ preference indices (Guroo et al. 2017).

\section{Conclusions}

It could be concluded that: (i) host plant affected the aphid palatability to the ladybird, which explains the contrary reports of suitability about $A$. craccivora to its predatory ladybird, (ii) D. lablab was a better host to raise palatable $A$. craccivora to $M$. sexmaculatus than $R$. sceleratus, (iii) similarly, $R$. sativus was better than $B$. campestris to culture L. erysimi, and (iv) M. sexmaculatus preferred $A$. craccivora over $L$. erysimi-infested toxic hosts in choice condition. Obtained results also explain the strong affinity of $M$. sexmaculatus with $A$. craccivora, as this predator is more witnessed in the vicinity of $A$. craccivora, regardless of the host plants.

\section{Acknowledgements}

Authors thank the Science and Engineering Research Board, Department of Science and Technology, Government of India for the financial assistance in the form of Major Research Project (EMR/2016/006296).

\section{Funding}

The present work is funded by the Science and Engineering Research Board, Department of Science and Technology, Government of India in the form of Major Research Project (EMR/2016/006296). AP is the project investigator, while SC is working as the project fellow in the said project.

\section{Authors' contributions}

AP has planned the outline of this research and designed the methodology. He did all the analyses and drafted the manuscript. SC assisted him in maintaining laboratory culture and performing experiments. Both the authors read and approved the final manuscript.

Ethics approval and consent to participate

Not applicable

\section{Consent for publication}

Not applicable

\section{Competing interests}

Both authors declare that they have no competing interests.

\section{Publisher's Note}

Springer Nature remains neutral with regard to jurisdictional claims in published maps and institutional affiliations.

Received: 14 April 2018 Accepted: 27 June 2018

Published online: 09 July 2018

\section{References}

Ahuja I, Rohloff J, Bones AM (2010) Defence mechanisms of Brassicaceae: implications for plant-insect interactions and potential for integrated pest management: a review. Agron Sustain Dev 30:311-348

Al-Snafi AE (2017) The pharmacology and medical importance of Dolichos lablab (Lablab purpureus) - a review. IOSR J Pharma 7:22-30

Chaplin-Kramer R, Kliebenstein DJ, Chiem A, Morrill, Mills NJ, Kremen C (2011) Chemically mediated tritrophic interactions: opposing effects of glucosinolates on a specialist herbivore and its predators. J Appl Ecol 48:880-887

Chaudhary DD, Kumar B, Mishra G, Omkar (2016) Food resource exploitation in ladybirds: consequences of prey species and size. Curr Sci 110:1343-1349

Cook MJW (1978) The assessment of preference. J Anim Ecol 47:805-816

Ferrer A, Dixon AFG, Hemptinne J-L (2008) Prey preference of ladybird larvae and its impact on larval mortality, some life-history traits of adults and female fitness. Bull Insect 61:5-10

Giorgi JA, Vandenberg NJ, McHugh JV, Forrester JA, Slipinski SA, Miller KB, Shapiro LR, Whiting MF (2009) The evolution of food preferences in Coccinellidae. Biol Control 51:215-231

Guroo MA, Pervez A, Srivastava K, Gupta RK (2017) Effect of nutritious and toxic prey on food preference of a predaceous ladybird, Coccinella septempunctata (Coleoptera: Coccinellidae). Eur J Entomol 114:400-406

Hachelaf A, Zellagui A, Touil A, Rhouati S (2013) Chemical composition and analysis antifungal properties of Ranunculus arvensis L. Pharmacophore 4:89-91

Hodek I (1996) Food relationships. Ecology of Coccinellidae (eds. I. Hodek and A. Honek). Kluwer, Dordrecht, pp 143-238

Hodek I, Evans EW (2012) Food relationship. Ecology and behaviour of ladybird beetles (Coccinellidae) (eds. I. Hodek, H.F. van Emden \& A. Honek). WileyBlackwell, West Sussex, pp. 141-274

Hodek I, van Emden HF, Honek I (2012) Ecology and behaviour of the ladybird beetles (Coccinellidae). Wiley-Blackwell, Oxford, p 531

Jaba J, Haseena B, Tripathy S, Hosamani AC, Amaresh YS (2010) Olfactory response of cowpea aphid, Aphis craccivora Koch, to host odours and population of conspecifics. J Biopesticides 3(1):405-407

Manly BFJ (1972) Tables for the analysis of selective predation experiments. Res Popul Ecol 14:74-81

Michaud JP (2005) On the assessment of prey suitability in aphidophagous Coccinellidae. Eur J Entomol 102:385-390 
Nedved O, Salvucci S (2008) Ladybird Coccinella septempunctata (Coleoptera: Coccinellidae) prefers toxic prey in laboratory choice experiment. Eur J Entomol 105:431-436

Obatake H, Suzuki H (1985) On the isolation and identification of canavanine and ethanolamine contained in the young leaves of black locus, Robinia pseudoaccacia, lethal for the ladybeetle, Harmonia axyridis. Tech Bull Fac Agric Kagawa Univ 36:107-115

Omkar, Bind RB (1998) Prey preference of a ladybird beetle, Cheilomenes (=Menochilus) sexmaculata (Fabr.). J Aphidol 12:63-66

Omkar, Bind RB (2004) Prey quality dependent growth, development and reproduction of a biocontrol agent, Cheilomenes sexmaculata (Fabricius) (Coleoptera: Coccinellidae). Biocont Sci Technol 14:665-673

Omkar, Mishra G (2005) Preference-performance of a generalist predatory ladybird: a laboratory study. Biol Control 34:187-195

Omkar, Pervez A (2016) Ladybird beetles. In: Omkar (ed) Ecofriendly pest management for food security. Academic Press, London, UK, Chapter 9, pp $281-310$

Pervez A, Kumar R (2017) Preference of the aphidophagous ladybird, Propylea dissecta for two species of aphids reared on toxic host plants. Eur J Environ Sci 7:130-134

Pervez A, Pooja, Bozdoğan H (2018) Predation potential of a biocontrol agent, Hippodamia variegata against the aphid, Aphis gossypii. J Bio Innov 7:185-192

Pratt C (2008) Accumulation of glucosinolates by the cabbage aphid Brevicoryne brassicae as a defense against two coccinellid species. J Chem Ecol 34:323-329

Provost C, Lucas E, Coderre D, Chouinard G (2006) Prey selection by the ladybeetle Harmonia axyridis: the influence of prey mobility and prey species. $J$ Insect Beh 19:265-277

Rana JS, Dixon AFG, Jarošík V (2002) Costs and benefits of prey specialization in a generalist insect predator. J Anim Ecol 71:15-22

Saleem M, Hussain D, Anwar H, Saleem M, Ghouse G, Abbas M (2014) Predation efficacy of Menochilus sexmaculatus Fabricius (Coleoptera: Coccinellidae) against Macrosiphum rosae under laboratory conditions. J Entomol Zool Studies 2:160-163

SAS, 9.0 (2002) SAS/Stat Version 9, SAS Institute Inc., Cary, NC, USA

Sherratt TN, Harvey IF (1993) Frequency — dependent food selection by arthropods a review. Biol I Linn Soc 48:167-186

Singh YP, Meghwal HP, Singh SP (2008) Biology and feeding potential of Cheilomenes sexmaculata Fabricius (Coleoptera: Coccinellidae) on mustard aphid. Ann Arid Zone 47:185-190

Sloggett JJ (2008a) Habitat and dietary specificity in aphidophagous ladybirds (Coleoptera: Coccinellidae): explaining specialization. Proc Netherlands Ent Soc Meet 19:95-113

Sloggett JJ (2008b) Weighty matters: body size, diet and specialization in aphidophagous ladybird beetles (Coleoptera: Coccinellidae). Eur J Entomol 105:381-389

\section{Submit your manuscript to a SpringerOpen ${ }^{\circ}$ journal and benefit from:}

- Convenient online submission

- Rigorous peer review

Open access: articles freely available online

- High visibility within the field

Retaining the copyright to your article 